\title{
KOMPARASI BIAYA UPAH PEKERJAAN BETON BERDASARKAN ANALISA KONVENSIONAL DENGAN ANALISA MODERN
}

\author{
Siti Nurasiyah ${ }^{1}$, Rochany Natawidjana ${ }^{2}$, dan Budi Kudwadi ${ }^{3}$ \\ ${ }^{1}$ Program Studi Teknik Sipil, Universitas Pendidikan Indonesia, Jl. Dr. Setiabudhi No. 229 Bandung \\ iisnurasiyah82yahoo.com \\ ${ }^{2}$ Program Studi Teknik Sipil, Universitas Pendidikan Indonesia, J1. Dr. Setiabudhi No. 229 Bandung \\ any.rochanymonza@gmail.com \\ ${ }^{3}$ Program Studi Teknik Sipil, Universitas Pendidikan Indonesia, J1. Dr. Setiabudhi No. 229 Bandung \\ bkudwadi@yahoo.com
}

\begin{abstract}
ABSTRAK
Anggaran biaya merupakan salah satu unsur fungsi perencanaan proyek konstruksi. Penyusunan anggaran merupakan perencanaan secara detail perkiraan biaya bagian atau keseluruhan kegiatan proyek, yang selanjutnya digunakan untuk menerapkan fungsi pengawasan dan pengendalian biaya serta waktu pelaksanaan. Perhitungan anggaran biaya biaya terdiri dari 5 (lima) hal yang pokok, yaitu tenaga kerja, bahan, alat, overhead, dan profit. Tenaga kerja merupakan salah satu sumber daya proyek yang menentukan keberhasilan proyek harus memiliki kualifikasi, keterampilan dan keahlian yang sesuai dengan kebutuhan untuk mencapai sasaran proyek. Salah satu faktor yang harus dipertimbangkan dalam merencanakan tenaga kerja adalah produktivitas tenaga kerja. Perhitungan anggaran biaya dengan menggunakan analisa modern menetapkan produktivitas tenaga kerja secara jelas dan lebih detail sesuai dengan ukuran dari bahan yang digunakan dan masing-masing rincian aktivitas, dengan satuan waktunya jam. Tujuan penelitian ini adalah untuk mengetahui besar biaya upah dengan analisa konvensional (AHSP) dan analisa modern pada pekerjaan beton bertulang, serta untuk mengetahui besar perbedaan biaya upah pekerjaan beton dengan analisa konvensional (AHSP) dan analisa modern. Hasil yang ingin dicapai dalam penelitian ini adalah dapat mengetahui komparasi besarnya biaya upah pada pekerjaan beton bertulang yang diamati berdasarkan analisa konvensional (AHSP) dan analisa modern. Besar biaya upah pekerjaan beton dengan Analisa Konvensional (AHSP PU) adalah sebesar Rp 78.320.606. Besar biaya upah pekerjaan beton dengan Analisa Modern (koefisien rendah) adalah sebesar Rp 22.828.020, sedangkan biaya pekerjaan beton dengan Analisa Modern (koefisien tinggi) adalah sebesar Rp 46.688.319. Selisih biaya RAB upah pekerjaan beton antara AHSP Kementerian Pekerjaan Umum dengan Analisa Modern (koefisien rendah) adalah sebesar Rp 55.492.585 (70,85\%), sedangkan selisih biaya RAB upah pekerjaan beton AHSP Kementerian Pekerjaan Umum dengan Analisa Modern (koefisien tinggi) adalah sebesar Rp 31.632 .287 (30,39\%). Biaya upah pada pekerjaan beton dengan menggunakan AHSP Kementerian Pekerjaan Umum meliputi biaya langsung dan biaya tidak langsung termasuk biaya umum (overhead), transportasi, dan lain-lain, sehingga perlu diidentifikasi berapa besar biaya tak langsung yang disisipkan pada produktivitas tenaga kerja dan biaya satuan pada AHSP Kementerian Pekerjaan Umum, untuk mendapatkan biaya aktual pelaksanaan di lapangan.
\end{abstract}

Kata kunci: analisa modern, analisa konvensional, AHSP, RAB

\begin{abstract}
The calculation cost is one of element function of project construction planning. The calculation arrangement is a planning as detail of approximation of cost part or the whole of project activity, which then is used to implement the function of monitoring and cost control also the realization time. The calculation of cost consists of five base thing, that is employee, material, tool, overhead, and profit. Employee is one of energy source of project which certain the success of project. Meanwhile the success of project itself must have qualifications, skills, and expertness that is suitable to the needy to get project target. One of factor that must be considered in planning the employee is employee productivity. The calculation of cost by using modern analysis determines the employee productivity clearly and more detail appropriate with the size that is used and its details of activity, with the unit of a clock time. The purpose of this research to know the much of cost fee with the conventional analysis (AHSP) and modern analysis on the bony concrete work, also to know the big different of cost fee on bony work with conventional analysis (AHSP) and modern analysis. The result that wants to be achieved in this research is able to know the big comparative of cost fee on bony concrete work which is analyzed based on conventional analysis (AHSP) and modern analysis. The big of cost fee on bony concrete work with conventional analysis (AHSP PU) is as much 78.320 .606 rupiahs. The big of cost fee on bony work with modern analysis (low coefficient) is as much 22.828.020 rupiahs; meanwhile the bony work fee with modern analysis (high coefficient) is as much 46.688.319 rupiahs. The quarrel of RAB fee of bony work between AHSP of the ministry of Common Work with modern analysis (low coefficient) is as much 55.492.585 rupiahs or $(70,85 \%)$, meanwhile the quarrel of RAB fee of concrete work AHSP of the ministry of Common Work with modern analysis (high coefficient) is as much 31.632.287 (30,39\%) rupiahs. The cost fee on concrete work by using AHSP of The ministry of common work includes the direct fee and indirect fee belonging to common fee (overhead), transportation, and others, so it is need to identified how much the indirect fee which is inserted on employee productivity and unit fee on AHSP of the ministry of Common Work, to get actual fee of implementation in the field.
\end{abstract}

Keyword: modern analysis, conventional analisys, AHSP, RAB 


\section{PENDAHULUAN}

Anggaran biaya merupakan salah satu unsur fungsi perencanaan proyek konstruksi. Penyusunan anggaran merupakan perencanaan secara detail perkiraan biaya bagian atau keseluruhan kegiatan proyek, yang selanjutnya digunakan untuk menerapkan fungsi pengawasan dan pengendalian biaya dan waktu pelaksanaan. Biaya yang diperlukan untuk suatu proyek dapat mencapai jumlah yang sangat besar dan tertanam dalam kurun waktu yang cukup lama. Keberhasilan proyek konstruksi ditentukan oleh penerapan Manajemen Konstruksi sesuai dengan pentahapannya (perencanaan, pelaksanaan, dan pengawasan). Dalam setiap pentahapan ini Rencana Anggaran Biaya (RAB) sangat berperan penting atas keberhasilan proyek. Sumber daya manusia atau tenaga kerja merupakan salah satu sumber daya proyek sebagai penentu keberhasilan proyek harus memiliki kualifikasi, keterampilan dan keahlian yang sesuai dengan kebutuhan untuk mencapai sasaran proyek. Salah satu faktor yang harus dipertimbangkan dalam merencanakan tenaga kerja adalah produktivitas tenaga kerja. Produktivitas kelompok pekerja adalah kemampuan tenaga kerja dalam menyelesaikan pekerjaan (satuan volume pekerjaan) yang dibagi dalam satuan waktu, jam atau hari. Produktivitas dapat digunakan untuk menentukan jumlah tenaga kerja beserta upah yang harus dibayarkan.

Permasalahan yang dapat diidentifikasi diantaranya adalah: (1) Berapa besar biaya upah pekerjaan beton dengan analisa konvensional (SNI); (2) Berapa besar biaya upah pekerjaan beton dengan analisa modern; dan (3) Berapa besar perbedaan upah pekerjaan beton dengan analisa konvensional (SNI) dan analisa modern.

Tujuan penelitian adalah sebagai berikut: (1) Mengetahui besar biaya upah pekerjaan beton dengan analisa konvensional (SNI); (2) Mengetahui besar biaya upah pekerjaan beton dengan analisa modern; dan (3) Mengetahui besar perbedaan upah pekerjaan beton dengan analisa konvensional (SNI) dan analisa modern.

Biaya tidak langsung seperti overhead, profit dan pajak tidak diperhitungkan.

Hasil Penelitian; hasil yang ingin dicapai dalam penelitian ini adalah dapat mengetahui besarnya biaya upah pada pekerjaan beton bertulang yang diamati berdasarkan analisa konvensional (SNI) dan analisa modern.

Urgensi Penelitian: Penaksiran anggaran biaya merupakan proses perhitungan volume pekerjaan, harga dari berbagai macam bahan dan pekerjaan yang akan terjadi pada suatu konstruksi suatu proyek yang biayanya dapat mencapai jumlah yang sangat besar. Karena taksirannya dibuat sebelum dimulainya pembangunan maka jumlah ongkos yang diperoleh adalah taksiran biaya bukan biaya sebenarnya. Perhitungan anggaran biaya dengan menggunakan analisa modern menetapkan produktivitas tenaga kerja secara jelas dan lebih detail sesuai dengan masing-masing rincian aktivitas, sehingga diharapkan dengan perhitungan anggaran biaya dengan analisa modern mendapatkan hasil perhitungan anggaran biaya yang lebih mendekati dengan biaya sebenarnya.

Tinjauan pustaka dalam kegaitan ini adalah:

\subsection{Rencana Anggaran Biaya}

Anggaran biaya proyek dapat didefinisikan sebagai perencanaan biaya yang akan dikeluarkan sehubungan adanya suatu proyek dengan rencana kerja dan syarat-syarat (RKS) tertentu, yang dihitung oleh cost estimator dan disetujui oleh pemberi tugas (pemilik).

Penaksiran anggaran biaya adalah proses perhitungan volume pekerjaan, harga dari berbagai macam bahan dan pekerjaan yang akan terjadi pada suatu konstruksi. Karena taksirannya dibuat sebelum dimulainya pembangunan maka jumlah ongkos yang diperoleh adalah taksiran biaya bukan biaya 
sebenarnya. (Soedradjat, 1984)

Biaya yang diperlukan untuk suatu proyek dapat mencapai jumlah yang sangat besar, oleh karena itu perlu identifikasi biaya proyek dengan tahapan perencanaan biaya proyek sebagai berikut: (Abrar Husein, 2010)

1. Tahapan pengembangan konseptual, biaya dihitung secara global berdasarkan informasi desain yang minim. Dipakai perhitungan berdasarkan unit biaya bangunan berdasarkan harga per meter persegi.

2. Tahapan desain konstruksi, biaya proyek dihitung secara agak detail berdasarkan volume pekerjaan dan informasi harga satuan.

3. Tahapan pelelangan, biaya proyek dihitung oleh beberapa kontraktor agar didapat penawaran terbaik, berdasarkan spesifikasi teknis dan gambar kerja yang cukup dalam usaha mendapatkan kontrak pekerjaan.

4. Tahapan pelaksanaan, biaya proyek pada tahapan ini dihitung lebih detail berdasarkan kuantitas pekerjaan, gambar shopdrawing, dan metode pelaksanaan dengan ketelitian yang lebih tinggi.

Pada tahap perencanaan selain gambar rencana dan spesifikasi, konsultan perencana juga menghitung rencana anggaran biaya bangunan demikian juga kontraktor akan membuat rencana anggaran biaya konstruksi (RAB) untuk penawaran.

Untuk membuat Rencana Anggaran Biaya Konstruksi diperlukan input data: (1) Gambar rencana, gambar potongan, detail; (2) Spesifikasi dan Rencana Kerja; (3) Harga satuan Material, Harga satuan Peralatan, Harga satuan Upah; dan (4) Informasi yang berkaitan dengan faktor-faktor yang mempengaruhi harga satuan material, harga satuan peralatan dan harga satuan upah.

Perhitungan anggaran biaya terdiri dari 5 hal yang pokok (Soedrajat, 1984), yaitu: (1) Bahan, menghitung banyaknya bahan yang dipakai dan harganya; (2) Buruh, menghitung jam kerja yang diperlukan dan jumlah biayanya; (3) Peralatan, menghitung jenis dan banyaknya peralatan yang digunakan dan biayanya; (4) Overhead, menghitung biaya-biaya yang tidak terduga yang perlu diadakan; dan (5) Profit, menghitung prosentase keuntungan dari waktu, tempat, dan jenis pekerjaan.

Proses penyusunan rencana anggaran biaya konstruksi adalah sebagai berikut: (1) Menjabarkan Lingkup Kegiatan Proyek Konstruksi atau disebut Work Break Down Structure (WBS); (2) Membuat Organisasi pelaksanaan atau disebut Organization Analysis Tabel (OAT ) untuk RAB yang dibuat oleh kontraktor; (3) Integrasi antara WBS dan OAT untuk RAB yang dibuat oleh kontraktor; (4) Menghitung Volume masingmasing pekerjaan (sesuai dengan WBS); (5) Menganalisis Harga Satuan (Menetapkan AHS yang akan digunakan); (6) Menetapkan Harga Satuan Pekerjaan; dan (7) Membuat Rencana Anggaran Biaya

\subsection{Volume Pekerjaan}

Volume pekerjaan sering disebut juga Bill of Quantity (BOQ) adalah salah satu proses dalam perhitungan RAB, Sebagaimana lingkup proyek yang telah dijabarkan sampai dengan suatu paket pekerjaan, maka perhitungan volume dari masing-masing paket pekerjaan (work package, WP) sesuai dengan karakteristik jenis pekerjaannya. Dasar perhitungan volume adalah gambar rencana yang dibuat oleh konsultan perencana.

Daftar kuantitas dan harga atau Bill of Quantity (BOQ) adalah daftar rician kebutuhan bahan pekerjaan yang disusun secara sistematis menurut kelompok/ bagian pekerjaan, disertai keterangan mengenai volume dan satuan setiap jenis pekerjaan, mata uang, harga satuan, hasil kali volume dengan harga satuan setiap jenis pekerjaan dan jumlah seluruh hasil pekerjaan sebagai 
total harga pekerjaan.

Beberapa satuan volume pekerjaan yang umum digunakan dalam proyek konstruksi, diantaranya adalah:

1. Is (lump sum), dipakai untuk menyatakan volume pekerjaan yang mempunyai biaya tetap meskipun terjadi perubahan volume pekerjaan.

2. m (meter), dipakai untuk menyatakan satuan panjang, yang dalam bahasa sehari-hari disebut dengan "meter lari".

3. $\mathrm{m}^{2}$ (meter persegi), dipakai untuk menyatakan satuan luas.

4. $\mathrm{m}^{3}$ (meter kubik), dipakai untuk menyatakan satuan isi.

5. unit; dipakai untuk menyatakan volume pekerjaan yang menyangkut item pekerjaan yang dapat dinyatakan sebagai suatu kesatuan, misalnya tangga yang sebenarnya terdiri dari anak tangga, bordes pegangan dan lainlain, tetapi dapat dinyatakan dalam satuan unit tangga.

6. buah, biasanya dinyatakan untuk satuan pekerjaan yang bahannya sudah dibeli dalam bentuk barang jadi dan pekerjaan di proyek hanya memasang saja.

\subsection{Analisa Harga Satuan Pekerjaan (AHSP)}

Analisis Harga Satuan Pekerjaan (AHSP) adalah perhitungan kebutuhan biaya tenaga kerja, bahan, dan peralatan untuk mendapatkan harga satuan atau satuan jenis pekerjaan tertentu. Harga satuan pekerjaan terdiri atas biaya langsung dan biaya tak langsung.

Komponen biaya langsung terdiri atas upah, bahan, dan alat, sedangkan biaya tak langsung terdiri atas biaya umum (overhead) dan keuntungan yang besarnya disesuaikan dengan ketentuan yang berlaku, biaya umum (overhead) dan keuntungan belum termasuk pajak-pajak yang harus dibayar, besarnya sesuai dengan ketentuan yang berlaku.

Setelah melakukan perhitungan volume pekerjaan selesai maka selanjutnya menetapkan harga satuan pekerjaan. Harga satuan pekerjaan/harga satuan adalah salah satu faktor penting dalam menentukan biaya proyek. Aspek teknik lebih menonjol dalam proses menghitung volume pekerjaan tetapi dalam proses menghitung harga satuan aspek bisnis juga menjadi pertimbangannya. Strategi penetapan harga satuan menyangkut strategi kontraktor dalam menghadapi persaingan dan dalam upaya untuk dapat memperoleh keuntungan yang lebih baik

Unsur harga satuan ini merupakan faktorfaktor yang mempengaruhi harga satuan pekerjaan/sub pekerjaan. Pada komponen biaya proyek konstruksi, unsur-unsur ini sebagai biaya langsung karena harga dasar dari unsur-unsur ini mempunyai data yang dapat dipastikan. Untuk memperoleh sumber yang paling layak bagi seluruh sumber daya yang diperlukan, harus dilakukan suatu survei yang cukup memadai. Tahap berikutnya setelah diperoleh semua informasi yang diperlukan, masih diperlukan lagi keterampilan khusus yaitu negosiasi. Negosiasi ini dapat diperoleh harga yang sangat kompetitif karena dari sumber yang sama, seseorang dapat memperoleh harga yang berbeda dengan orang lain, karena pengaruh keberhasilan dalam negosiasi. Dalam kegiatan yang bersifat bisnis, peranan negosiasi sangat penting sekali, karena akan berpengaruh pada keputusan suatu harga. Pada dasarnya setiap orang yang terlibat dalam kegiatan bisnis, harus memahami seluk beluk tentang negosiasi, untuk dapat berhasil dalam suatu negosiasi (baik bisnis maupun non bisnis), harus mendapatkan semua informasi yang diperlukan, dapat mengendalikan waktu sebaik-baiknya, mempunyai kekuatan atau mampu mengurangi kelemahan sendiri, sebelum melakukan negosiasi.

Harga satuan pada dasarnya terdiri dari tiga unsur, yaitu upah tenaga kerja, bahan (materials), dan alat (Equipments). Sumber daya manusia atau tenaga kerja sebagai penentu keberhasilan proyek harus memiliki 
kualifikasi, keterampilan dan keahlian yang sesuai dengan kebutuhan untuk mencapai sasaran proyek.

Analisa harga satuan upah suatu pekerjaan adalah menghitung banyaknya tenaga yang diperlukan, serta besarnya biaya yang dibutuhkan untuk pekerjaan tersebut. (Bachtiar Ibrahim, 1993). Secara umum jumlah tenaga kerja yang dibutuhkan untuk suatu volume pekerjaan tertentu dapat dicari dengan rumus:

$\Sigma$ Tenaga Kerja $=$ Volume Pekerjaan $\mathrm{x}$ Koefisien analisa tenaga kerja (SNI)

\subsection{Analisa Modern}

\subsubsection{Perhitungan Tenaga Kerja}

Perhitungan analisa modern dan analisa konvensional dalam menganalisa tenaga kerja sama-sama menggunakan koefisien dalam satu satuan pekerjaan / dalam satu volume yang ditetapkan.

Perbedaan antara perhitungan analisa modern dan analisa konvensional dalam menganalisa tenaga kerja adalah :

- Produktivitas tenaga kerja ditetapkan secara jelas dengan satuan waktunya adalah jam

- Produktivitas tenaga kerja lebih detail sesuai dengan ukuran dari bahan yang digunakan dan masing-masing rincian aktivitas

- Upah tidak dihitung dengan harian tetapi dengan jam

Upah tidak dihitung untuk setiap jenis tenaga kerja tetapi dihitung dari rata-rata upah dari berbagai jenis tenaga kerja. Perhitungan analisa modern dalam menganalisa tenaga kerja adalah:

- Menghitung jam kerja/ durasi yang dibutuhkan masing-masing pekerjaan

- Menghitung upah rata-rata dari jumlah tenaga kerja yang digunakan

- Menghitung RAB upah untuk volume tersebut

Biaya buruh sangat dipengaruhi oleh bermacam-macam hal, di antaranya panjang jam kerja yang diperlukan untuk menyelesaikan suatu jenis pekerjaan, keadaan tempat bekerja, keterampilan, dan keahlian buruh yang bersangkutan.

Waktu yang diperlukan untuk mengerjakan suatu jenis pekerjaan tergantung dari keahlian, sikap mental dari pekerja tersebut terhadap pekerjaan itu dan juga tergantung dari keadaan setempat. Keadaan setempat dan peraturan-peraturan buruh kadangkadang mempengaruhi besarnya upah, dan upah per jam dapat berubah-ubah. Cara yang baik untuk menaksir biaya upah adalah dengan menaksir jumlah jam kerja yang diperlukan untuk setiap jenis pekerjaan yang dipisahkan dari upah buruh, kemudian hasilnya dikalikan dengan upah per jam atau per hari (Soedradjat, 1984).

\subsubsection{Pekerjaan Konstruksi Beton}

Pekerjaan konstruksi beton dapat dibagi dalam beberapa bagian, yaitu : kayu cetakan (bekesting), penulangan, dan cor beton. Perhitungan produktivitas tenaga kerja pada analisa modern dihitung lebih detail sesuai dengan ukuran dari bahan yang digunakan dan masing-masing rincian aktivitas.

1. Kayu cetakan (bekisting), dihitung dalam $\mathrm{m}^{2}$

Pada tabel 1, disajikan keperluan tenaga buruh untuk keperluan cetakan beton

Pada umumnya jam kerja akan berkurang apabila dipakai kayu lapis sebagai ganti papan biasa. Membasahi atau mengoles permukaan dengan minyak memakan waktu dari beberapa menit sampai satu jam untuk permukaan seluas $10 \mathrm{~m} 2$. (Soedradjat, 1984)

Cetakan dapat dibuat dari plat besi, meskipun harganya mahal tapi dapat dipergunakan berulang kali sehingga akan jauh lebih murah. Upah buruh untuk memasang, 
Tabel 1

Keperluan Tenaga Buruh untuk Pekerjaan Cetakan Beton

\begin{tabular}{|c|c|c|c|c|c|}
\hline \multirow[b]{2}{*}{ No } & \multirow[b]{2}{*}{ Jenis Cetakan Kayu } & \multicolumn{4}{|c|}{ Jam kerja tiap luas cetakan $10 \mathrm{~m} 2$} \\
\hline & & Menyetel & memasang & $\frac{\text { membuka dan }}{\text { membersihkan }}$ & Reparasi \\
\hline 1 & Pondasi / Pangkal Jembatan & 3 sampai 7 & 2 sampai 4 & 2 sampai 4 & 2 sampai 5 jam untuk \\
\hline 2 & Dinding & 5 sampai 9 & 3 sampai 5 & 2 sampai 5 & segala jenis pekerjaan \\
\hline 3 & Lantai & 3 sampai 8 & 2 sampai 4 & 2 sampai 4 & \\
\hline 4 & Atap & 3 sampai 9 & 2 sampai 5 & 2 sampai 4 & \\
\hline 5 & Tiang - Tiang & 4 sampai 8 & 2 sampai 4 & 2 sampai 4 & \\
\hline 6 & Kepala Tiang & 5 sampai 11 & 3 sampai 7 & 2 sampai 5 & \\
\hline 7 & Balok - Balok & 6 sampai 10 & 3 sampai 4 & 2 sampai 5 & \\
\hline 8 & Tangga & 6 sampai 12 & 4 sampai 8 & 3 sampai 5 & \\
\hline 9 & $\begin{array}{l}\text { Sudut - sudut tiang atau Balok } \\
* \text { berukir }\end{array}$ & 5 sampai 11 & 3 sampai 9 & 3 sampai 5 & \\
\hline 10 & Ambang Jendela dan Lintel & 5 sampai 10 & 3 sampai 6 & 3 sampai 5 & \\
\hline
\end{tabular}

Tabel 2

Keperluan Tenaga Buruh untuk Pekerjaan Cetakan dengan Pelat Besi

\begin{tabular}{clcc}
\hline No & Jenis Pekerjaan & $\begin{array}{l}\text { Jam Kerja tiap } 10 \mathrm{~m} 2 \\
\text { luas cetakan }\end{array}$ & $\begin{array}{l}\mathrm{m} 2 \text { luas permukaan cetakan } \\
\text { setiap jam kerja }\end{array}$ \\
\hline 1 & Menyetel dan Memasang & 2 sampai 6 & 1,5 sampai 4,5 \\
\hline 2 & Membongkar dan membersihkan & 1 sampai 4 & 2,25 sampai 9 \\
\hline 3 & Perbaikan Kecil & 1 sampai 3 & 2,95 sampai 9 \\
\hline & Jumlah & 4 sampai 13 & 0,75 sampai 2,25 \\
\hline
\end{tabular}

Sumber: (Soedradjat, 1984)

Tabel 3

Jam Kerja Buruh yang diperlukan untuk Membuat 100 bengkokan dan Kaitan

\begin{tabular}{|c|c|c|c|c|}
\hline \multirow{2}{*}{ Ukuran besi beton $\varnothing$} & \multicolumn{2}{|c|}{ Dengan Tangan } & \multicolumn{2}{|c|}{ Dengan Mesin } \\
\hline & Bengkokan, (jam) & Kait, (jam) & Bengkokan, (Jam) & Kait, (Jam) \\
\hline 1-1/2" (12mm) Kebawah & $2-4$ & $3-6$ & $0.8-1.5$ & $1.2-2.5$ \\
\hline \multicolumn{5}{|l|}{$2-5 / 8 ”(16 \mathrm{~mm})$} \\
\hline 3/4" (19 mm) & $2.5-5$ & $4-8$ & $1-2$ & $1.6-3$ \\
\hline \multicolumn{5}{|l|}{$7 / 8 "(22 \mathrm{~mm})$} \\
\hline \multicolumn{5}{|l|}{ 3-1" (25 mm), } \\
\hline $11 / 8 "(28.5 \mathrm{~mm})$ & $3-6$ & $5-10$ & $1.2-2.5$ & $2-4$ \\
\hline \multicolumn{5}{|l|}{ 4-1/4" (31.75 mm), } \\
\hline $11 / 2 "(38.1 \mathrm{~mm})$ & $4-7$ & $6-12$ & $1.5-3$ & $2.5-5$ \\
\hline
\end{tabular}

Tabel 4

Jam Kerja Buruh yang diperlukan untuk Membuat 100 Batang Tulangan

\begin{tabular}{|c|c|c|c|}
\hline \multirow{2}{*}{ Ukuran besi beton $\varnothing$} & \multicolumn{3}{|c|}{ Panjang Batang Tulangan } \\
\hline & Dibawah $3 \mathrm{~m}$ & $3-6 m$ & $6-9 \mathrm{~m}$ \\
\hline 1-1/2" (12 mm) kebawah & $3.5-6$ & $5-7$ & $6-8$ \\
\hline $2-5 / 8 "(16 \mathrm{~mm}), 3 / 4 "(19 \mathrm{~mm})$ & $4.5-7$ & $6-8.5$ & $7-9.5$ \\
\hline \multicolumn{4}{|l|}{$7 / 8 ”(22 \mathrm{~mm})$} \\
\hline \multicolumn{4}{|l|}{$3-1 "(25 \mathrm{~mm})$} \\
\hline $11 / 8 ”(28.5 \mathrm{~mm})$ & $5.5-8$ & $7-10$ & $8.5-11.5$ \\
\hline \multicolumn{4}{|l|}{ 4-1 1/4“(31.75 mm) } \\
\hline $11 / 2 " 38.1 \mathrm{~mm})$ & $6.5-9$ & $8-12$ & $10-14$ \\
\hline
\end{tabular}


membersihkan, membongkar cetakan pelat besi akan lebih murah daripada menyetel, memasang, membongkar, dan membersihkan cetakan kayu.

2. Penulangan, dihitung dalam ton atau $\mathrm{kg}$

Tulangan beton dihitung berdasarkan beratnya dalam $\mathrm{kg}$ atau ton. Para pelaksana biasanya membuat daftar

Tabel 5

Jam Kerja Buruh yang diperlukan untuk mencampur, menaruh di dalam cetakan dan memeliharanya sesudah ditaruh cetakan (Curing)

\begin{tabular}{lc}
\hline \multicolumn{1}{c}{ Jenis Campuran } & Jam kerja setiap \\
\cline { 2 - 2 } 1. Mencampur beton dengan tangan & m3 betonan \\
\hline 2. Mencampur beton dengan mesin pengaduk & $1.31-2.62$ \\
\hline 3. Mencampur beton dengan memanaskan air dan agregat & $0.65-1.57$ \\
\hline 4. Memasang Pondasi - pondasi & $0.92-1.97$ \\
\hline 5. Memasang tiang - tiang dan dinding tpis & $1.31-5.24$ \\
\hline 6. Memasang dinding tebal & $2.62-6.55$ \\
\hline 7. Memasang lantai & $1.31-5.24$ \\
\hline 8. Memasang tangga & $1.31-5.25$ \\
\hline 9. Memasang beton struktural & $3.93-7.86$ \\
\hline 10. Memasang beton struktural pada cuaca dingin (di luar negeri) & $1.31-5.24$ \\
\hline 11. Memelihara beton & $2.62-6.55$ \\
\hline 12. Memelihara beton pada cuaca dingin, dan memanaskannya & $0.65-1.31$ \\
\hline 13. Mengaduk, memasang dan memeliharanya & $1.31-6.55$ \\
\hline 14. Mengaduk, Memasang dan memeliharanya pada cuaca dingin & $2.62-7.86$ \\
\hline
\end{tabular}

khusus pembengkokan tulangan, dimana dapat dilihat dengan jelas bentuk pembengkokannya, panjangnya, banyaknya danjuga sisa pemotongan. Sisa pemotongan dapat diketahui banyaknya dan panjangnya dan dapat dipakai untuk penulangan lain. Banyaknya tenaga buruh yang diperlukan tergantung dari banyaknya pembengkokan dan pemotongan, banyaknya besi sengkang yang dipakai. Untuk pemotongan besi beton diperlukan waktu antara 1 sampai 3 (Soedradjat, 1984)

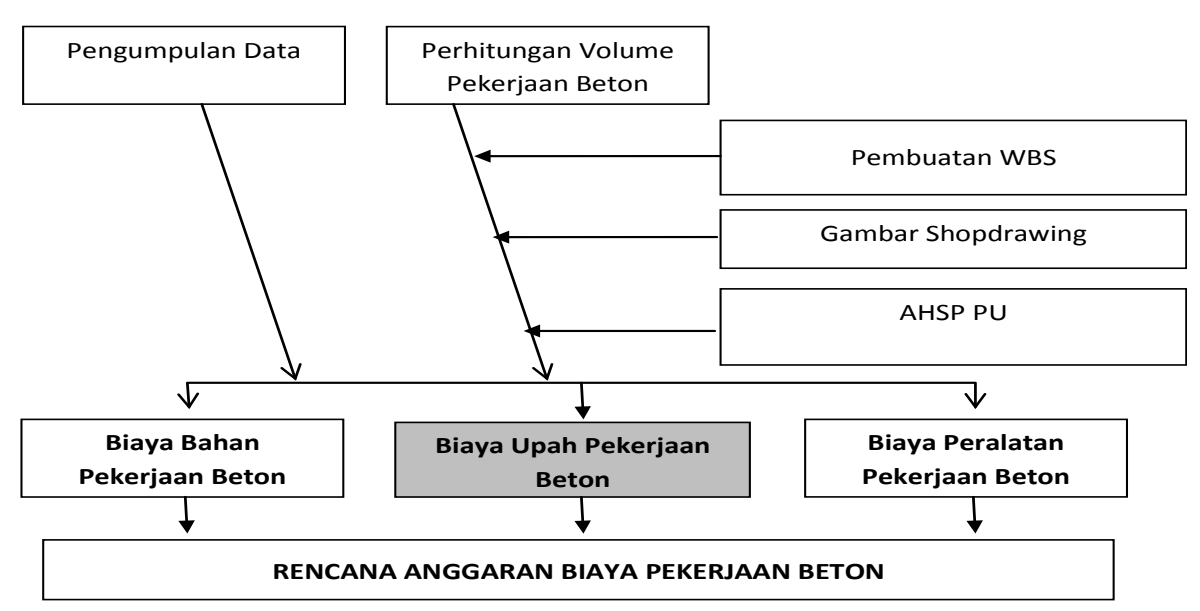

Diagram Posisi Penelitian

jam untuk 100 batang tulangan tergantung dari diameternya, alat-alat potongnya, dan keterampilan buruhnya. 
3. Cor Beton, dihitung dalam $\mathrm{m}^{3}$

Langkah pertama untuk menghitung biaya cor beton adalah menghitung volume dari campuran-campuran beton, satuan yang dipakai biasanya $\mathrm{m} 3$. Tenaga kerja diperlukan untuk mencampur beton, mengangkut, dan menaruhnya di cetakan-cetakan yang sudah ada. Bila digunakan ready mix maka buruh tidak diperlukan untuk mencampur beton.

\section{METODE PENELITIAN}

Kegiatan penelitian dilaksanakan dalam waktu 8 (delapan) bulan dengan lokasi penelitian di Bandung, dengan analisis penelitian bertempat di kampus FPTK UPI.

Untuk mendapatkan biaya upah pekerjaan beton, langkah-langkah analisis dilakukan sebagai berikut: (1) Pengumpulan Data Gambar rencana arsitek dan struktur (gambar bestek); (2) Menjabarkan Lingkup Kegiatan Proyek Konstruksi atau disebut Work Break Down Structure (WBS); (2) Menghitung Volume masing-masing pekerjaan ( sesuai dengan WBS); (3) Menganalisis Harga Satuan Upah (Menetapkan AHS yang akan digunakan); (4) Menetapkan Harga Satuan Pekerjaan; (5) Membuat Rencana Anggaran Biaya Berdasarkan Metoda Konvensional; (6) Menghitung jam kerja/ durasi yang dibutuhkan masing-masing pekerjaan; (7) Menghitung upah rata-rata dari jumlah tenaga kerja yang digunakan; dan (8) Menghitung $\mathrm{RAB}$ upah dengan analisa modern.

Tabel 6

Rekapitulasi Hasil Perhitungan RAB Upah antara Analisa Konvensional (AHSP PU) dan Analisa Modern

\begin{tabular}{|c|c|c|c|c|c|c|c|}
\hline \multirow{3}{*}{ No } & \multirow{3}{*}{ Jenis Pekerjaan } & \multicolumn{6}{|c|}{ Penulangan } \\
\hline & & \multirow{2}{*}{\multicolumn{2}{|c|}{ Analisa PU }} & \multicolumn{4}{|c|}{ Analisa Modern } \\
\hline & & & & \multicolumn{2}{|c|}{ Koef. Rendah } & \multicolumn{2}{|c|}{ Koef. Tinggi } \\
\hline 1. & Pekerjaan Pondasi & $\mathrm{Rp}$ & $7,234,418$ & $\mathrm{Rp}$ & $2,819,248$ & $\mathrm{Rp}$ & $6,122,314$ \\
\hline 2. & Pekerjaan Beton & & & & & & \\
\hline 2.1. & Pekerjaaan Kolom & $\mathrm{Rp}$ & $24,024,503$ & $\mathrm{Rp}$ & $6,641,947$ & $\mathrm{Rp}$ & $12,649,109$ \\
\hline 2.2. & Pekerjaan Balok & $\mathrm{Rp}$ & $13,684,234$ & $\mathrm{Rp}$ & $3,923,555$ & $\mathrm{Rp}$ & $7,906,110$ \\
\hline 2.3 . & Pekerjaan Sloof & $\mathrm{Rp}$ & $5,889,911$ & $\mathrm{Rp}$ & $2,274,165$ & $\mathrm{Rp}$ & $4,481,256$ \\
\hline 2.4. & Pekerjaan Tangga & $\mathrm{Rp}$ & $1,975,806$ & $\mathrm{Rp}$ & 957,649 & $\mathrm{Rp}$ & $2,087,750$ \\
\hline 2.5. & Pekerjaan Ring Balk & $\mathrm{Rp}$ & $7,130,917$ & $\mathrm{Rp}$ & $2,937,307$ & $\mathrm{Rp}$ & $5,718,662$ \\
\hline 2.6. & Pekerjaan Plat lantai & $\mathrm{Rp}$ & $17,821,925$ & $\mathrm{Rp}$ & $2,756,555$ & $\mathrm{Rp}$ & $6,509,580$ \\
\hline 2.7. & Pekerjaan Dak beton & $\mathrm{Rp}$ & 558,890 & $\mathrm{Rp}$ & 517,594 & $\mathrm{Rp}$ & $1,213,537$ \\
\hline & Total Upah & $\mathrm{Rp}$ & $78,320,606$ & $\mathrm{Rp}$ & $22,828,020$ & $\mathrm{Rp}$ & $46,688,319$ \\
\hline
\end{tabular}

\section{HASIL DAN PEMBAHASAN}

Setelah melakukan perhitungan RAB upah dengan Analisa Modern, didapat bahwa perhitungan $\mathrm{RAB}$ upah dengan Analisa Modern lebih efisien dan lebih rendah biayanya, karena perhitungannya dijabarkan secara mendetail. Selisih biaya RAB upah pekerjaan beton antara AHSP Kementerian Pekerjaan Umum dengan Analisa Modern (koefisien rendah) adalah sebesar Rp 55.492 .585 (70,85\%), sedangkan selisih biaya RAB upah pekerjaan beton AHSP
Kementerian Pekerjaan Umum dengan Analisa Modern (koefisien tinggi) adalah sebesar Rp 31.632.287 (30,39\%).

Biaya upah pada pekerjaan beton dengan menggunakan AHSP Kementerian Pekerjaan Umum meliputi biaya langsung dan biaya tidak langsung termasuk biaya umum (overhead), transportasi, dan lain-lain, sehingga perlu diidentifikasi berapa besar biaya tak langsung yang disisipkan pada produktivitas tenaga kerja dan biaya satuan pada AHSP Kementerian Pekerjaan Umum, 
untuk mendapatkan biaya aktual pelaksanaan di lapangan.

\section{KESIMPULAN}

Kesimpulan yang dapat diambil dari hasil penelitian ini adalah sebagai berikut:

1. Besar biaya upah pekerjaan beton dengan Analisa Konvensional (AHSP PU) adalah sebesar Rp 78.320.606.

2. Besar biaya upah pekerjaan beton dengan Analisa Modern (koefisien rendah) adalah sebesar Rp22.828.020, sedangkan biaya pekerjaan beton dengan Analisa Modern (koefisien tinggi) adalah sebesar Rp 46.688.319.

3. Selisih biaya RAB upah pekerjaan beton antara AHSP Kementerian Pekerjaan Umum dengan Analisa Modern (koefisien rendah) adalah sebesar Rp 55.492 .585 (70,85\%), sedangkan selisih biaya RAB upah pekerjaan beton AHSP Kementerian Pekerjaan Umum dengan Analisa Modern (koefisien tinggi) adalah sebesar Rp 31.632.287 (30,39\%). Biaya upah pada pekerjaan beton dengan menggunakan AHSP Kementerian Pekerjaan Umum meliputi biaya langsung dan biaya tidak langsung termasuk biaya umum (overhead), transportasi, dan lainlain, sehingga perlu diidentifikasi berapa besar biaya tak langsung yang disisipkan pada produktivitas tenaga kerja dan biaya satuan pada AHSP Kementerian Pekerjaan Umum, untuk mendapatkan biaya aktual pelaksanaan di lapangan.

\section{DAFTAR PUSTAKA}

Abrar Husen, 2010, Manajemen Proyek, PT. Andi, Yogyakarta.

Asiyanto, 2005, Construction Project Cost Management, PT Kresna Prima Persada, Jakarta

B, N Duta, 1996 Estimating and Costing In Civil Engineering, UBS, New Delhi.

Gambar Bestek, 2004, Belaputera Intiland, Kota Baru Parahyangan.

Iman Soeharto, 1997, Manajemen Proyek dari Konseptual sampai Operasional

Kementerian Pekerjaan Umum, 2013, Analisis Harga Satuan Pekerjaan Umum (AHSP) Bidang Pekerjaan Umum, Jakarta.

Soedradjat, 1984, Anggaran Biaya Pelaksanaan (Analisa Modern), Nova.

Wulfram L Ervianto, 2005, Manajemen Proyek Konstruksi, Andi, Yogyakarta. 